\title{
PENGEMBANGAN MEDIA PROMOSI POTENSI DESA OEPUAH DENGAN MENGGUNAKAN METODE WATERFALL
}

\author{
DEVELOPMENT OF PROMOTIONAL MEDIA FOR OEPUAH VILLAGE \\ POTENTIALITY USING WATERFALL METHOD
}

\author{
Krisantus Jumarto Tey Seran ${ }^{1)}$, Victoria Nova Naiheli ${ }^{2)}$ \\ ${ }^{1,2}$ )Program Studi Teknologi Informasi, Fakultas Pertanian, Universitas Timor \\ Jl. Km. 09, Kelurahan Sasi, Kecamantan Kota Kefamemanu, TTU, NTT, 85613
}

Copyright ( 2021 , JITU, submitted:11 Desember 2020; Revised: 03 February 2021; Accepted: 14 February 2021; Published: 01 Maret 2021

\begin{abstract}
Oepuah Village is one of the villages that has a lot of local potentiality to be promoted such as agricultural products, livestock, fisheries, and local wisdom of the local community. The problem faced today is that the information regarding the local potentiality of the Oepuah village cannot be currently accessed by the public for the delivery of information can only be obtained when someone visits the local village office. Seeing this problem, it is necessary to build a promotional website that can be used to help introduce the local potentiality of this area to the outside world online. To set up this website, we use the waterfall method, a method which systematically provides a workflow approach to software. The result of this study may help provide convenience in providing complete information about the surrounding countrysides, as well as promote the potentiality of a very significant local agriculture, the potentiality of livestock, fisheries and culture so that it can be known by the public.
\end{abstract}

Keywords - Website, Online Promotion, Waterfall Method.

\begin{abstract}
Abstrak - Desa Oepuah merupakan salah satu desa yang memiliki banyak potensi lokal untuk dipromosikan seperti hasil pertanian, peternakan, perikanan, dan kearifan lokal masyarakat setempat. Masalah yang dihadapi saat ini adalah Informasi tentang potensi lokal di Desa Oepuah saat ini belum dapat di akses oleh masyarakat karena penyampaian informasi hanya bisa diperoleh apabila langsung datang ke kantor desa setempat. Melihat masalah ini perlu dibangun sebuah website promosi yang dapat digunakan untuk membantu mengenalkan potensi lokal daerah ini ke dunia luar secara online. Dalam membangun website ini, digunakan metode waterfall yaitu merupakan metode yang menyediakan pendekatan alur hidup perangkat lunak secara sistematis. Hasil dari penelitian ini dapat membantu memberikan kemudahan dalam menyediakan informasi lengkap mengenai seputar desa maupun mempromosikan hasil potensi lokal unggulan yang sangat menononjolkan potensi pertanian, potensi peternakan, potensi perikanan dan budaya yang dapat di ketahui oleh masyarakat luas.
\end{abstract}

Kata kunci - Website, Promosi Online, Metode Waterfall.

\section{PENDAHULUAN}

Desa Oepuah terletak di kecamatan Biboki Moenleu, kabupaten Timor Tengah Utara. Desa ini memiliki potensi lokal unggulan seperti hasil pertanian, peternakan, perikanan dan hasil tenun. Penduduk Desa Oepuah rata-rata memiliki mata pencaharian sebagai petani, peternak, nelayan dan kearifan lokal buadaya daerah setempat, hal ini tercermin dari potensi yang telah disebutkan sebagai potensi unggulan. Sehingga dibutuhkan optimalisasi teknologi informasi dalam penyebaran informasi dan promosi.

Kebutuhan akan informasi bagi masyarakat desa setempat sangat besar tetapi yang tidak mendukung adalah adisebabkan karena kurangnya pengetahuan akan teknologi informasi dengan adanya penerapan sistem informasi berbasis website akan memberikan kemudahan kepada masyarakat untuk mengakses

\footnotetext{
*) Penulis Korespondensi (Krisantus J. Tey Seran) email: krisantusteyseran@unimor.ac.id
}

informasi secara cepat dan akurat yang sesuai dengan kebutuhan masyarakat baik masyarakat setempat maupun masyarakat luar.

Adapun sistem yang dibangun yaitu dengan menggunakan metode waterfall merupakan metode yang menyediakan pendekatan alur hidup perangkat lunak secara sistematis dan terurut dimulai dari analisa, desain, pengkodean, pengujian dan pendukung (Rosa \& Shalahuddin, 2013:28). Model waterfall paling banyak digunakan untuk tahap pengembangan. Model waterfall ini juga dikenal dengan nama model tradisional atau model klasik. Model air terjun (waterfall) sering juga disebut model sekuensial linier (squential linear) atau alur hidup klasik (Classic cycle) oleh (Susilo \& Kurniati, 2018). Adapun kelebihan dari metode waterfall dalam pengembangan perangkat lunak adalah kualitas dari website yang dihasilkan akan baik karena pelaksanaannya dilakukan dengan cara bertahap atau berurutan dari fase yang satu ke fase yang berikut sehingga meminimalis kesalahan atau error yang mungkin akan terjadi (Aceng Abdul Wahid, 2020). 
Sebelumnya sudah ada penelitian sejenis ini dengan judul "Pemanfaatan Media Sosial Sebagai Strategi Komunikasi Untuk Mempromosikan Potensi Lokal Wisata Pulau Bawean" oleh (Satvikadewi \& Hamim, 2018). Dalam Penelitian ini metode yang digunakan adalah analisis isi (content analysis). Analisis isi merupakan salah satu dari metode analisis teks. Pada penelitian ini membahas bagaimana penggunaan media sosial sebagai cara komunikasi untuk mempromosikan potensi lokal wisata Pulau Bawean.

Berdasarkan latar belakang di atas maka, tujuan dari penelitian ini adalah untuk untuk membangun sebuah website promosi untuk desa ini dengan judul "Rancang Bangun Website Media Promosi Potensi Lokal Desa Oepuah Menggunakan Metode waterfall". Website ini bertujuan untuk mempermudah pekerjaan aparat desa dalam melakukan proses penyebaran informasi dan mempromosikan hasil potensi lokal seperti hasil pertanian, peternakan perikanan kearifan lokal budaya seperti tenun ikat dan tarian likurai secara online sehingga berdampak pada peningkatkan pendapatan desa tersebut.

\section{METODE PENELITIAN}

\section{A. Website}

Website adalah keseluruhan kumpulan halaman web yang terdapat dalam sebuah domain yang mengandung informasi baik yang bersifat statis dan dinamis (Jimi, 2019). Adapun untuk mengakses dan pengambilan dokumen atau informasi website menggunakan aplikasi sebagai berikut:

\section{Web browser}

Sebuah situs web dapat diakses melalui aplikasi web browser. Menurut Sibero (2013), mengatakan bahwa web browser adalah aplikasi perangkat lunak yang digunakan untuk mengambil dan menyajikan sumber informasi web.

\section{Web server}

Web server yaitu sebuah computer yang terdiri dari perangkat keras dan perangkat lunak. Secara bentuk fisik dan cara kerjanya, perangkat keras web server tidak berbeda dengan komputer rumah atau PC, yang membedakannya adalah kapasitas dan kapabilitasnya (Putri et al., 2020).

\section{Apache}

Apache adalah web server yang dapat dijalankan dibanyak sistem operasi seperti (Unix, BSD, Linux, Microsoft Windows dan Novell Netware serta Platform lainnya) yang bisa digunakan untuk menjalankan fungsi situs web (Putri et al., 2020).

\section{Internet}

Internet (Interconneted Network) merupakan jaringan komputer yang menghubungkan antar jaringan secara global, internet juga dapat disebut jaringan alam suatu jaringan yang luas. Selain web browser dan web server, ada juga jaringan seperti internet yang ikut serta dalam mengakses sebuah situs web (Putri et al., 2020).

\section{B. Media Promosi Online}

Media promosi online merupakan segala macam proses promosi dari sebuah produk atau jasa hingga ke tangan pembeli atau peminat semua menggunakan media digital. Dimana kinerja sebuah perusahaan tersebut berupa promosi, penjualan barang atau jasa, serta mengkomunikasikannya melalui internet. Media promosi adalah sarana yang digunakan untuk mengkomunikasikan seseorang agar bisa mengetahui suatu produk, jasa, profil dari suatu perusahaan. Salah satu bagian penting dari promosi adalah menentukan media promosi yang paling tepat misalnya seperti surat kabar, televisi, radio, majalah, web dan lain-lain (Dwi, 2017).

\section{Metode Waterfall}

Metode air terjun atau yang sering disebut metode waterfall juga dinamakan siklus hidup klasik (classic life cycle), nama model ini sebenarnya adalah "Linear Siquential Model" dimana hal ini menggambarkan pendekatan yang sistematis dan juga berurutan pada pengembangan perangkat lunak, dimulai dengan spesifikasi kebutuhan pengguna lalu berlanjut melalui tahapan-tahapan berupa perencanaan (planning), permodelan (modelling), kontuksi (contruction), serta penyerahan sistem ke pengguna, dan diakhiri dengan dukungan pada perangkat lunak lengkap yang dibangun (Aceng Abdul Wahid, 2020).

Pembuatan sistem menggunakan metode waterfall dikarenakan metode ini memiliki tahapan pengerjaan dilakukan secara berurut dan sistematis yang artinya jika tahapan pertama belum selesai maka tidak bisa lanjut ke tahap kerja yang berikutnya. Setiap tahapan saling terkait karena keluaran dari tahap pertama menjadi masukan untuk tahap berikut sehingga pengerjaan dari setiap tahapan harus diselesaikan dengan baik. Pemakaian metode ini sangat terorganisir karena setiap tahapan mempunyai proses dan dokumen sehingga mudah dalam pengembangan sesuai kebutuhan pengguna atau user (Rumetna \& Lina, 2020).

Berikut adalah tahapan-tahapan dari metode waterfall yang dapat dilihat pada gambar berikut:

\section{Requeirement}

Tahap ini pengembangan sistem dibutuhkan komunikasi dengan tujuan untuk memahami informasi kebutuhan perangkat lunak yang diharapkan oleh pengguna dan batasan perangkat lunak tersebut. Informasi diperoleh melalui wawancara, observasi dan studi pustaka keudian diolah dan dianalisa untuk mendapatkan data atau informasi yang lengkap untuk spesifikasi kebutuhan perangkat lunak yang dikembangkan.

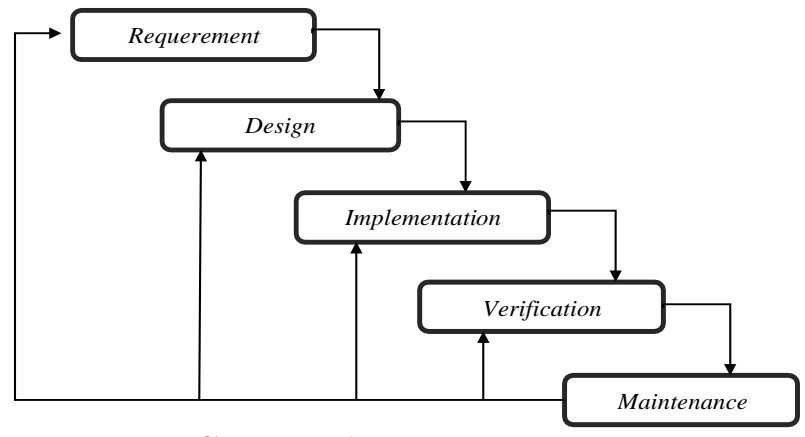

Gambar 1. Metode Waterfall Sumber: (Pressman, 2012) 


\section{Design}

Pada tahap ini perancangan desain dilakukan untuk membantu memberikan gambaran lengkap terkait apa yang dikerjakan. Tahap ini membantu mendefenisikan arsitektur sistem secara keseluruhan.

\section{Implementation}

Pada tahap ini merupakan tahap pemrograman. Sistem pertama kali dikembangkan di program kecil yang disebut unit, yang terintegrasi ke tahap selanjutnya. Setiap unit dikembangkan dan diuji dan memeriksa fungsionalitas unit yang dibuat sudah memenuhi kriteria pengguna atau belum.

\section{Verification/Testing}

Pada tahap ini, sistem dilakukan verifikasi dan pengujian sistem sepenuhnya atau sebagian memenuhi persyaratan sistem atau belum. Pengujian dapat diketegorikan ke dalam unit testing dilakukan pada modul tertentu kode, sistem pengujian untuk melihat bagaimana sistem bereaksi ketika semua modul yang terintegrasi dan penerimaan pengujian dilakukan dengan atau nama pelanggan untuk melihat semua kebutuhan pelanggan puas atau tidak.

\section{Maintenance}

Ini adalah tahap yang terakhir dimana perangkat lunak yang sudah jadi dijalankan oleh pengguna serta dilakukan pemeliharaan sehingga jika menemukan kesalahan maka akan diperbaiki atas kesalahan yang terdeteksi pada tahap-tahap sebelumnya. Pemeliharaan meliputi perbaikan kesalahan, perbaikan implementasi unit sistem, dan peningkatan dan penyesuaian sistem sesuai kebutuhan.

\section{HASIL DAN PEMBAHASAN}

\section{A. Hasil}

\section{Analisis Sistem Baru}

Berdasarkan permasalahan yang telah diperoleh dari wawancara, observasi dan analisis terhadap sistem lama, maka dikembangkan flowchart desain sistem baru untuk website media promosi potensi lokal desa Oepuah antara lain sebagai berikut:

\section{Analisis Sistem Baru}

Desain arsitektur yang dirancang bertujuan untuk hubungan antar elemen-elemen utama dari website ini. Desain arsitektur dapat dilihat dibawah ini:

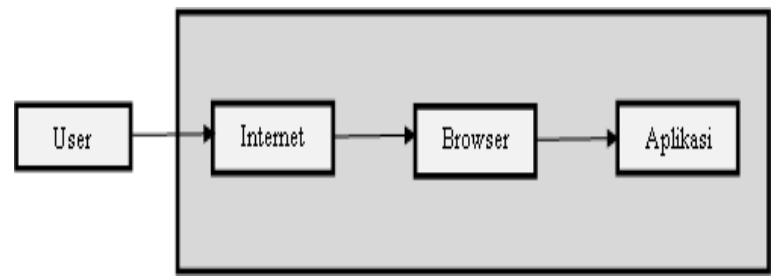

Gambar 2. Arsitektur Website Promosi Potensi Lokal Desa

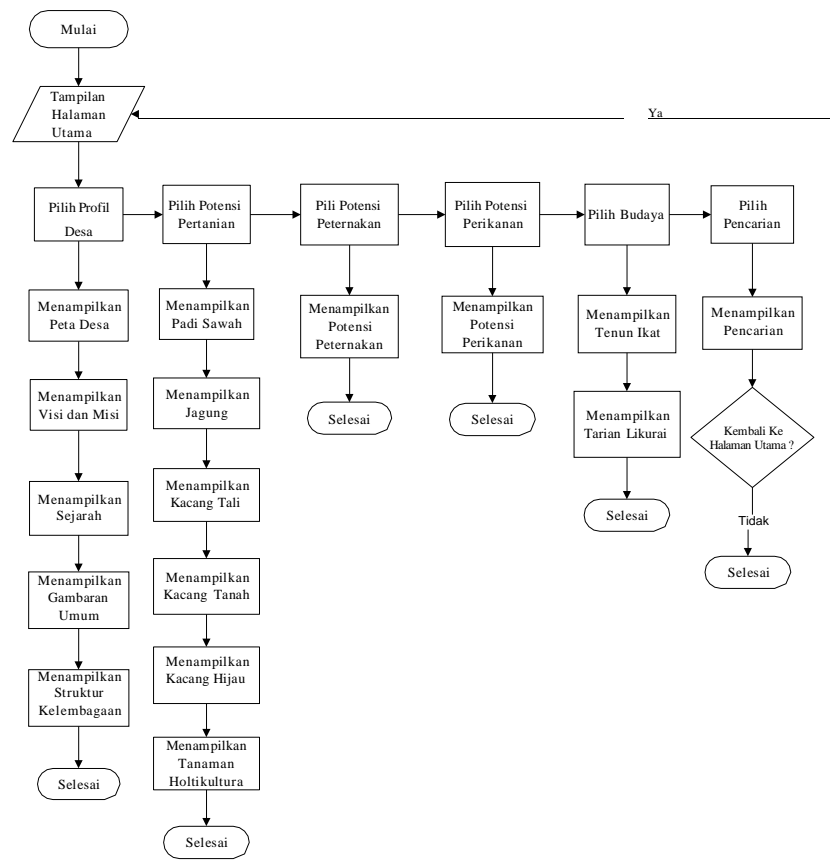

Gambar 3. Flowchart Promosi Potensi Lokal Desa

\section{Use Case Diagram}

Pada use case promosi potensi lokal desa, user dapat berinteraksi dengan sistem secara langsung. User bebas memilih informasi yang tersedia sesuai kebutuhan user. Use case diagram merupakan diagram yang menggambarkan interaksi antara user dan sistem. Gambar dibawah merupakan interaksi antara user dan sistem :

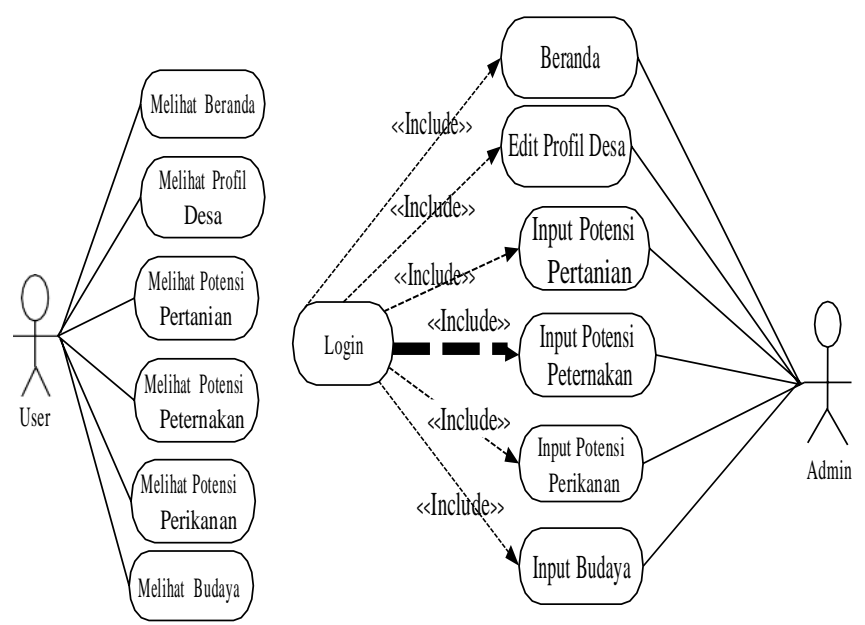

Gambar 4. Use Case Diagram Promosi Potensi Lokal Desa Oepuah

\section{B. Pembahasan}

Pada penelitian ini sistem dibangun menggunakan bahasa pemrograman PHP dengan basis data MySQL, aplikasi sistem pendukung tersebut adalah sebagai berikut:

Pada bagian ini, semua bagian yang telah dibahas pada bagian analisis dan perancangan akan diimplementasikan menjadi sebuah website media promosi potensi lokal desa Oepuah yang dibuat menggunakan wordpress.

\section{Halaman Menu Utama}

Halaman ini berisi Gambar, tombol home, tombol profil desa, tombol potensi pertanian, tombol potensi peternakan, tombol potensi perikanan, tombol budaya, 
ikon pencarian dan berita. Desain antarmuka halaman utama dapat dilihat pada gambar berikut ini:

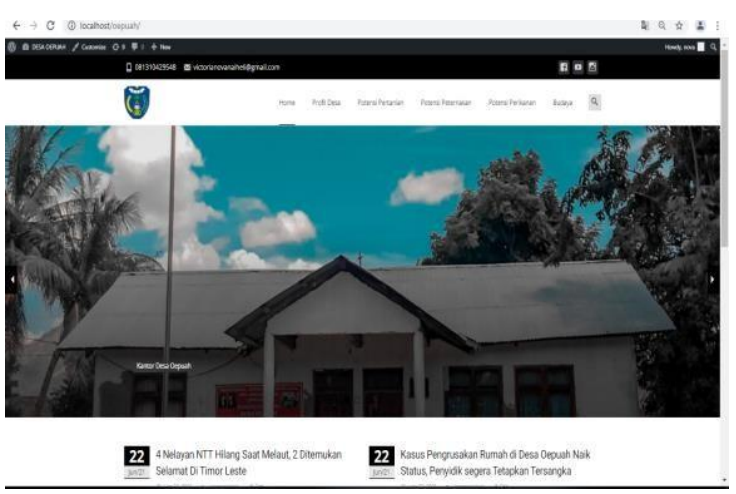

Gambar 5. Desain Antarmuka Halaman Utama

\section{Halaman Menu Profil Desa}

Halaman ini berisi tombol home, tombol profil desa, tombol potensi pertanian, tombol potensi peternakan, tombol potensi perikanan, tombol budaya, ikon pencarian dan menampilkan beberapa sub menu peta desa, visi-misi, sejarah, gambaran umum dan struktur kelembagaan. Desain antarmuka halaman profil desa dapat dilihat pada gambar dibawah ini:

\section{a. Halaman Sub Menu Peta Desa}

Halaman ini berisi informasi lengkap mengenai letak Desa Oepuah yang dapat dilihat pada gambar dibawah.

\section{Peta Dese}

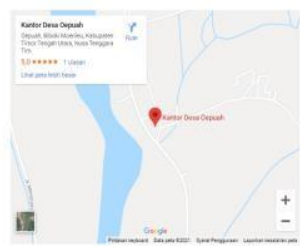

Gambar 6. Desain Antarmuka Halaman Peta Desa

b. Halaman Sub Menu Visi \& Misi

Halaman ini berisi informasi lengkap mengenai visi dan misi dari Desa Oepuah yang dapat dilihat pada gambar dibawah.
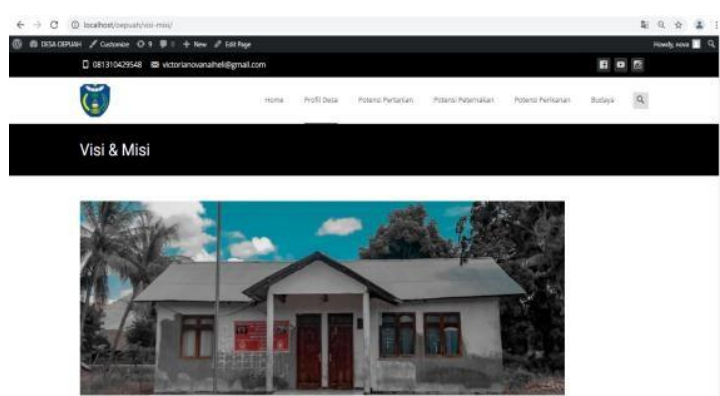

Gambar 7. Desain Antarmuka Halaman Visi dan Misi

c. Halaman Sub Menu Sejarah

Halaman ini berisi informasi sejarah lengkap mengenai Desa Oepuah, yang dapat dilihat pada gambar dibawah.

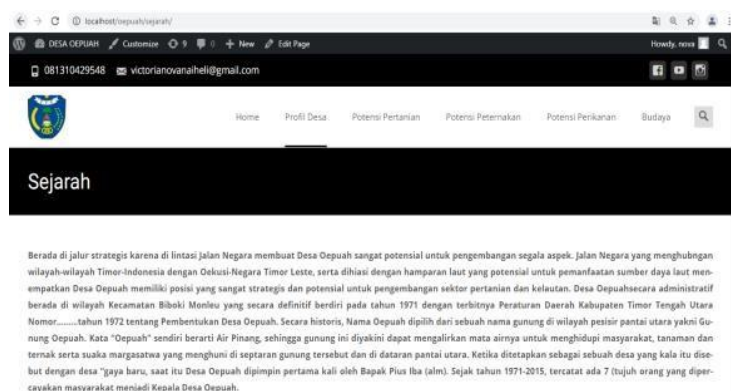

Gambar 8. Desain Antarmuka Halaman Sejarah

d. Halaman Sub Menu Sejarah

Halaman ini berisi informasi lengkap mengenai gambaran umum dari Desa Oepuah, yang dapat dilihat pada gambar dibawah.

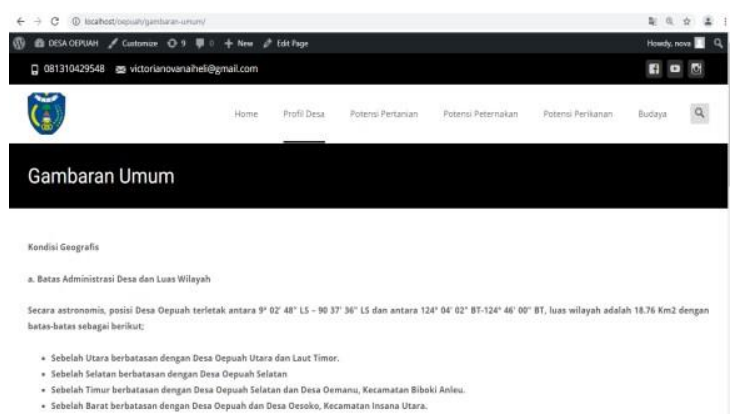

Gambar 9. Desain Antarmuka Halaman Gambaran Umum

e. Halaman Sub Menu Sejarah

Halaman ini berisi informasi lengkap mengenai struktur kelembagaan dan aparatur dari Desa Oepuah, yang dapat dilihat pada gambar dibawah.

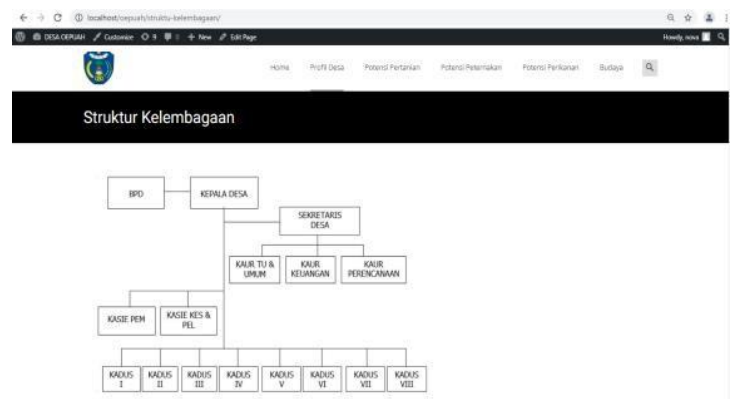

Gambar 10. Desain Antarmuka HalamanStruktur Kelembagaan

3. Halaman Menu Potensi Pertanian

Halaman ini berisi tombol home, tombol profil desa, tombol potensi pertanian, tombol potensi peternakan, tombol potensi perikanan, tombol budaya, ikon pencarian dan menampilkan beberapa sub menu padi sawah, jagung, kacang tali, kacang tanah, kacang hijau dan tanaman holtikultura. Desain antarmuka halaman potensi pertanian dapat dilihat pada gambar dibawah ini:

a. Halaman Sub Menu Padi Sawah

Halaman ini berisi informasi lengkap mengenai potensi padi sawah yang dihasilkan di Desa Oepuah yang dapat dilihat pada gambar dibawah. 

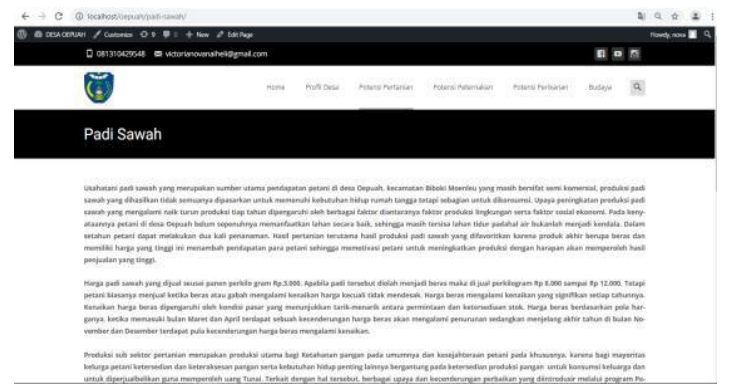

Gambar 11. Desain Antarmuka Halaman Padi Sawah

b. Halaman Sub Menu Jagung

Halaman ini berisi informasi lengkap mengenai potensi jagung yang dihasilkan di Desa Oepuah yang dapat dilihat pada gambar dibawah.

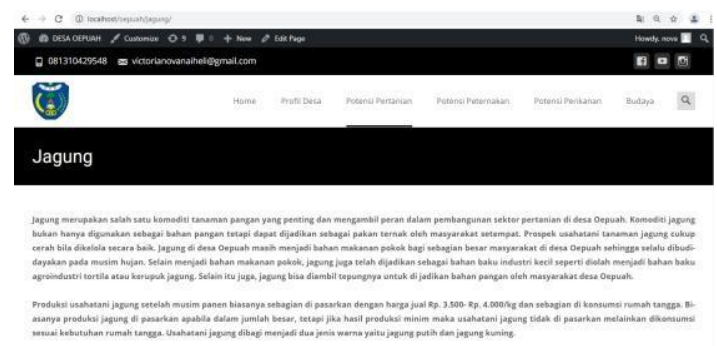

Gambar 12. Desain Antarmuka Halaman Jagung

c. Halaman Sub Menu Kacang Tali

Halaman ini berisi informasi lengkap mengenai potensi kacang tali yang dihasilkan di Desa Oepuah yang dapat dilihat pada gambar dibawah.
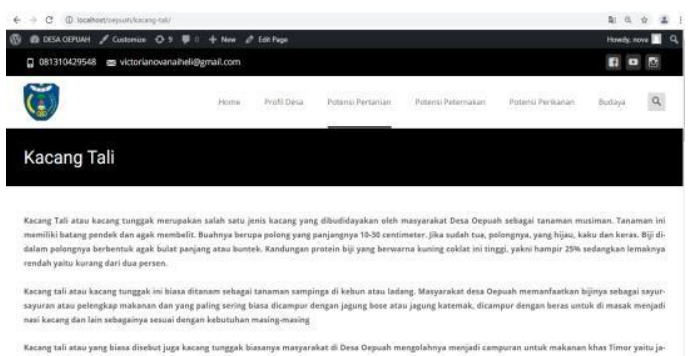

Gambar 13. Desain Antarmuka Halaman Kacang Tali

d. Halaman Sub Menu Kacang Tanah

Halaman ini berisi informasi lengkap mengenai potensi kacang tanah yang dihasilkan di Desa Oepuah yang dapat dilihat pada gambar dibawah.

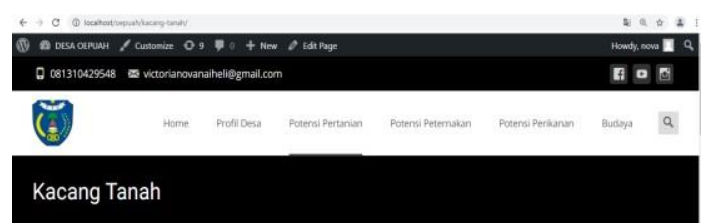

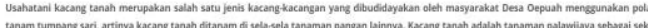

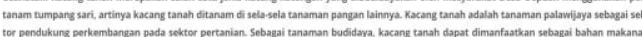

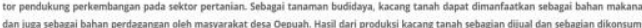

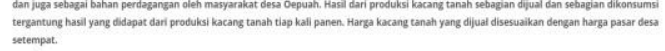

Gambar 14. Desain Antarmuka Halaman Kacang Tanah

e. Halaman Sub Menu Kacang Hijau

Halaman ini berisi informasi lengkap mengenai potensi kacang hijau yang dihasilkan di Desa Oepuah yang dapat dilihat pada gambar dibawah.

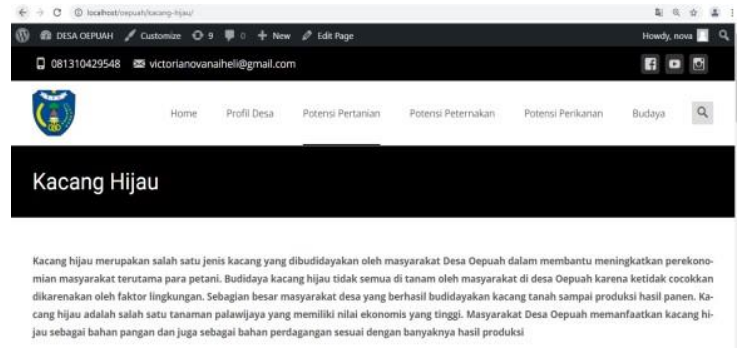

Gambar 15. Desain Antarmuka Halaman Kacang Hijau

f. Halaman Sub Menu Tanaman Holtikultura

Halaman ini berisi informasi lengkap mengenai potensi tanaman holtikultura yang dihasilkan di Desa Oepuah yang dapat dilihat pada gambar dibawah.
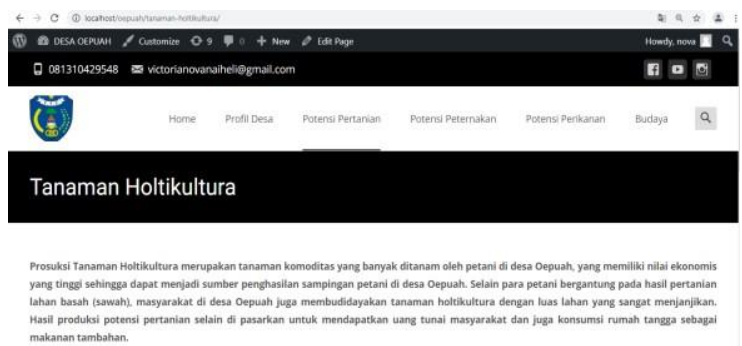

Gambar 16. Desain Antarmuka Halaman Tanaman Holtikultura

4. Halaman Menu Potensi Peternakan

Halaman ini berisi tombol home, tombol profil desa, tombol potensi pertanian, tombol potensi peternakan, tombol potensi perikanan, tombol budaya, ikon pencarian dan menampilkan informasi mengenai potensi peternakan yang ada di desa Oepuah. Desain antarmuka halaman potensi peternakan dapat dilihat pada gambar dibawah ini:
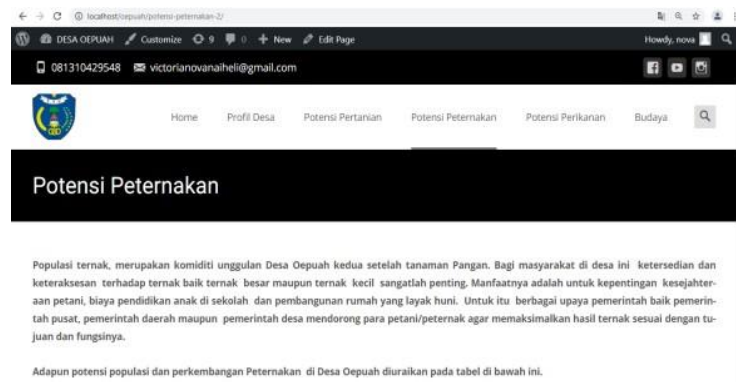

Gambar 17. Desain Antarmuka Halaman Potensi Peternakan

5. Halaman Menu Potensi Peternakan

Halaman ini berisi tombol home, tombol profil desa, tombol potensi pertanian, tombol potensi peternakan, tombol potensi perikanan, tombol budaya, ikon pencarian dan menampilkan informasi mengenai potensi peternakan yang ada di desa Oepuah. Desain antarmuka halaman potensi peternakan dapat dilihat pada gambar dibawah ini: 


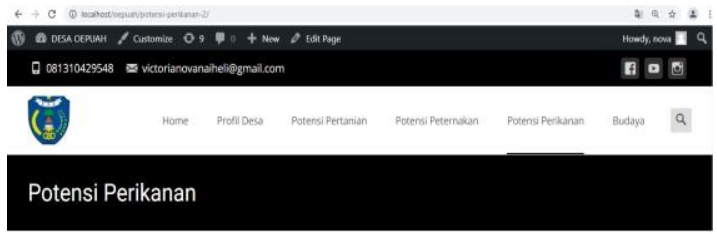

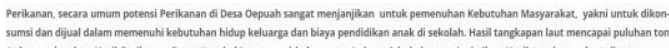

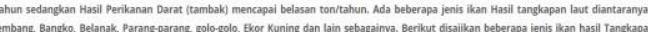

Gambar 18. Desain Antarmuka Halaman Potensi Perikanan

\section{Halaman Menu Budaya}

Halaman ini berisi tombol home, tombol profil desa, tombol potensi pertanian, tombol potensi peternakan, tombol potensi perikanan, tombol budaya, ikon pencarian dan menampilkan beberapa sub menu yaitu menu tenun ikat dan tarian likurai. Desain antarmuka halaman budaya dapat dilihat pada gambar dibawah ini:

a. Halaman Sub Menu Tenun Ikat

Halaman ini berisi informasi lengkap mengenai karifan lokal budaya yang dihasilkan berupa tenun ikat karya masyarakat di Desa Oepuah yang dapat dilihat pada gambar dibawah.
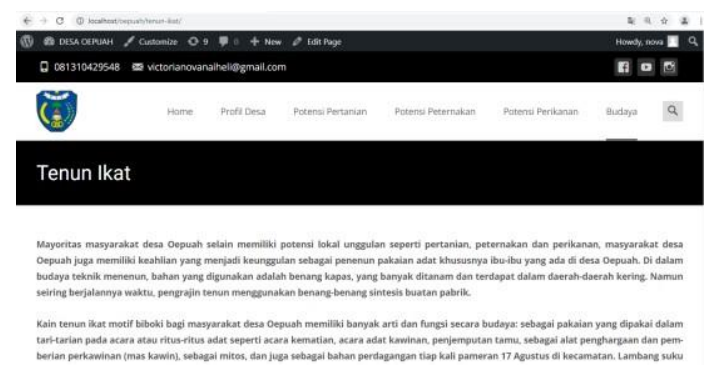

Gambar 19. Desain Antarmuka Halaman Tenun Ikat

b. Halaman Sub Menu Tarian Likurai

Halaman ini berisi informasi lengkap mengenai karifan lokal budaya yang dihasilkan berupa tarian likurai karya masyarakat di Desa Oepuah yang dapat dilihat pada gambar dibawah.
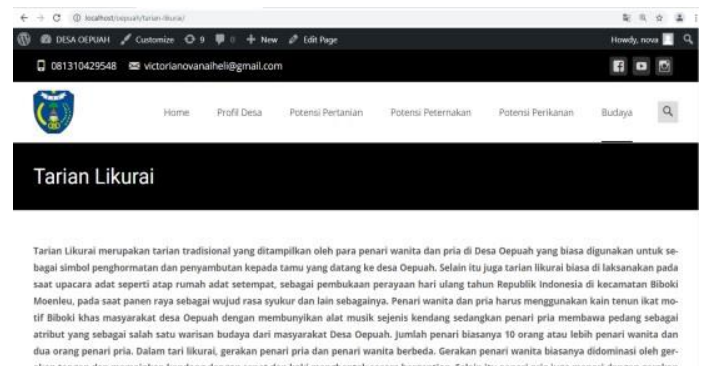

Gambar 20. Desain Antarmuka Halaman Tarian

Likurai

\section{IV.KESIMPULAN}

Berdasarkan beberapa serangkaian penelitian yang dilakukan, maka pada bab ini penulis mengambil kesimpulan dari uraian penelitian pada bab sebelumnya yaitu sebagai berikut:

1. Rancang bangun website media promosi potensi lokal Desa Oepuah dengan menggunakan metode waterfall telah berjalan dengan baik. Sudah dapat menampilkan semua menu, diantaranya menu tampilan halaman utama, menu profil desa, menu potensi pertanian, menu potensi peternakan, menu potensi perikanan dan menu budaya.

2. Penggunaan website media promosi potensi lokal desa ini dapat membantu terpublikasinya potensi-potensi lokal unggulan yang ada di Desa Oepuah secara luas, sehingga dapat berdampak pada peningkatan perekonomian masyarakat Desa Oepuah.

3. Penggunaan website media promosi potensi lokal ini dapat membantu memberikan kemudahan dalam menyediakan informasi lengkap mengenai seputar desa maupun mempromosikan hasil potensi lokal unggulan yang sangat menononjolkan potensi pertanian, potensi peternakan, potensi perikanan dan budayanya yang dapat di ketahui oleh masyarakat luas karena dapat diakses kapan saja dan dimana saja.

\section{DAFTAR PUSTAKA}

[1]. Aceng Abdul Wahid. (2020). Analisis Metode Waterfall Untuk Pengembangan Sistem Informasi. Jurnal Ilmu-Ilmu Informatika Dan Manajemen STMIK, October, 1-5.

[2]. Dwi, A. Q. A. (2017). Pembuatan Website Menggunakan Cms Wordpress. Jurnal Aplikasi Bisnis, 3,287-292.

http://jab.polinema.ac.id/index.php/jab/article/view/92 $/ \mathrm{Pdf}$

[3]. Jimi, A. (2019). Rancang Bangun Sistem Informasi Desa Berbasis Website (Studi Kasus Desa Netpala). Jurnal Pendidikan Teknologi Informasi (JUKANTI), 2(1), 1-7. https://doi.org/10.37792/jukanti.v2i1.17.

[4]. Putri, D., Gata, W., \& Warjiyono. (2020). Rancang Bangun Website Desa Demangharjo. Elkom: Jurnal Elektronika Dan Komputer, 13(2), 49-62. https://journal.stekom.ac.id/index.php/elkom/article/vi ew/237

[5]. Rumetna, M. S., \& Lina, T. N. (2020). Sistem Informasi Kampung Wisata Arborek Dengan Metode Waterfall. Information System For Educators And Professionals, 5(1), 31-40.

[6]. Satvikadewi, A. A. P., \& Hamim. (2018). Pemanfaatan Media Sosial sebagai Strategi Komunikasi untuk Mempromosikan Potensi Lokal Wisata Pulau Bawean. Seminar Hasil Penelitian Dan Pengabdian Masyarakat, 102-120. file:///D:/LKTI/NASKAH PUBLIKASI.pdf

[7]. Susilo, M., \& Kurniati, R. (2018). RANCANG BANGUN WEBSITE TOKO ONLINE MENGGUNAKAN METODE WATERFALL. 2(2), 98-105. 